\title{
Teleconnection between Cold ENSO Phases and Seasonal Rainfall Over Sri Lanka: Case Study in Kotmale Catchment
}

\author{
S.S.K. Chandrasekara, S.K. Chandrasekara, V. Prasanna and H-H. Kwon
}

\begin{abstract}
Cold ENSO phase or La-Nina is the least considered atmospheric oscillation in the hydro-meteorological sector in Sri Lanka. Therefore, this study focused on understanding teleconnection between cold ENSO phases and the seasonal rainfall over Kotmale catchment. Daily rainfall data of 9meteorological stations were used to investigate behaviour of annual rainfall climatologies of the catchment. Daily mean inflow data of Kotmale reservoir for the duration of 1984 2012 was analysed to understand the trends of the reservoir inflow. Sea surface temperature values were extracted from the Japan Meteorological Agency to determine cold ENSO phase. Rainfall trend for each station and inflow trend of the reservoir both declined throughout the selected time duration. However the rate of decreasing trend changes with each station. Seasonal rainfall of all the stations showed negative correlation with mean sea surface temperature over Nino 3 region for December to September. Cold ENSO phases encounter prominent above-average seasonal rainfall during and the onset of South-West monsoon. Further, onset and during of North-East monsoon rainfall over the catchment was weakened due to the impact of cold ENSO phase over Nino 3 region. However, further studies are suggested to identify hidden opposite phenomenon observed during cold ENSO phases on 1964 and 1967 in Kotmale catchment, where all the stations experienced worst below-average seasonal rainfall.
\end{abstract}

Keywords: $\quad$ Cold ENSO phases, Seasonal rainfall, Kotmale

\section{Introduction}

The El-Nino Southern Oscillation (ENSO) phenomenon is one of the primary modes of seasonal climatic variability, particularly in the tropics [1]. ENSO is a shift in the pattern of oceanic warming and atmospheric circulation centered in the Pacific Ocean with implications across the tropics that recurs typically 2-7 years apart. The phases of the ENSO phenomena associated with warmer and colder than normal seas surface in the equatorial Central and Eastern pacific oceans are referred to as El Nino (warm ENSO phase) and La Nina (cold ENSO phase), respectively. Neutral ENSO phase associated when the oscillation is neither in a warm nor cold phase. Many studies showed ENSO is one of the phenomena which influences on rainfall over Sri Lanka[1], [2], [3], [4], [5], [6], [7], [8], [9], [10], [11]. Supplementary, there is a strong link between seasonal rainfall anomalies and the ENSO events of Sri Lanka[4], [12], [13], [14]. Further, due to the alteration in intensity and location of Walker cell, the climate of Sri Lanka is governed during ENSO extremes [15].

World Meteorological Organization (WMO) has considered as La Niña occurs on average every
3 to 5 years. However, National Oceanic and Atmospheric Administration (NOAA) determined an interval between events vary from 2-7 years [16] according to the historical records. La Niña conditions typically last approximately 9-12 months. Nevertheless, some episodes may persist for as long as two years.

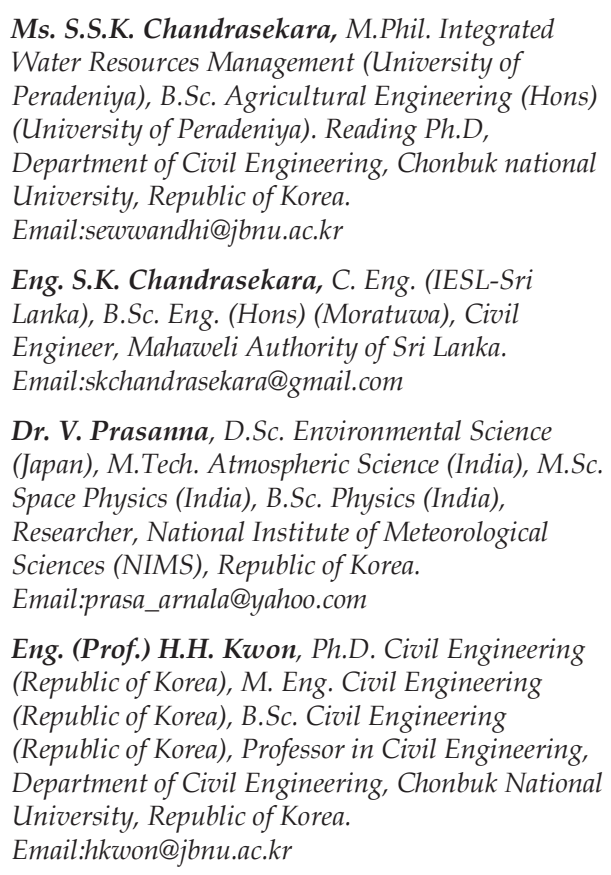

Ms. S.S.K. Chandrasekara, M.Phil. Integrated Water Resources Management (University of Peradeniya), B.Sc. Agricultural Engineering (Hons) (University of Peradeniya). Reading Ph.D,

Department of Civil Engineering, Chonbuk national University, Republic of Korea.

Email:sewwandhi@jbnu.ac.kr

Eng. S.K. Chandrasekara, C. Eng. (IESL-Sri Lanka), B.Sc. Eng. (Hons) (Moratuwa), Civil Engineer, Mahaweli Authority of Sri Lanka. Email:skchandrasekara@gmail.com

Dr. V. Prasanna, D.Sc. Environmental Science (Japan), M.Tech. Atmospheric Science (India), M.Sc. Space Physics (India), B.Sc. Physics (India), Researcher, National Institute of Meteorological Sciences (NIMS), Republic of Korea.

Email:prasa_arnala@yahoo.com

Eng. (Prof.) H.H. Kwon, Ph.D. Civil Engineering (Republic of Korea), M. Eng. Civil Engineering (Republic of Korea), B.Sc. Civil Engineering (Republic of Korea), Professor in Civil Engineering, Department of Civil Engineering, Chonbuk National University, Republic of Korea.

Email:hkwon@jbnu.ac.kr 
Majority of cold extreme (La Nina) events caused above-normal-rainfall over the IndoAustralian region [1]. The La Nina events caused massive flood for Thailand (in1938 and 1970) and Singapore (in1954) [1]. During March to December 1988 a heavy monsoonal rainfall occurred in the upper basin areas in India and caused heavy flooding in downstream Bangladesh due to the presence of La Nina event. In 1998, a La Nina event similar to that of 1988 brought heavy rains to Bangladesh and caused flooding [17]. North-East Monsoon (NEM) rainfall for the 1958-1980 and 1981-2002, the La Nina conditions were associated with a tendency towards drier conditions for South Asia [18], [19], [20].

During 1881 to 1990 the monthly rainfall (i.e. October, November and December) over 29 stations of Sri Lanka had 14\%,10\% and 12\% decrease during cold ENSO phases, respectively [11]. During 1881 to 1990, first inter-monsoon (FIM) and NEM had not shown clear influence by the cold ENSO phases, but South-Western Monsoon (SWM) and second inter-monsoon (SIM) had significant abovenormal-rainfall and negative rainfall anomalies in the presence of cold ENSO phase, respectively [11]. Cold ENSO phases were associated with a marked decrease in average rainfall over upper Mahaweli Catchment during October to March [18]. The rest of the months showed increase in average rainfall for the region. The average Yala rainfall (i.e. rainfall between May and August)was13\% higher than that during the El Nino on average for Kelani river catchment. Furthermore, during October to December rainfall decreases during ENSO cold phase [13]. It is found that the influence of La Nina on seasonal rainfall except during FIM is significant when the initiation of the event occur in month of April or May [19].

As discussed in above, concern on teleconnection between the cold ENSO phases over rainfall over Sri Lanka is negligible compared to the studies concerned on the teleconnection between the warm ENSO and rainfall over Sri Lanka. Therefore, this study aimed to identify teleconnection between ENSO cold phase and seasonal rainfall over Kotmale catchment in Sri Lanka.

\section{Study Area}

Kotmale reservoir is one of the multipurpose reservoirs (i.e. hydro-power generation, irrigation, alleviating flood and flow regulator) built in Sri Lanka in 1980's [12], [22], [23]. It is the uppermost reservoir in irrigation complex of Sri Lanka[22] and maintaining required level of storage volume of the Kotmale reservoir is very vital. Though the Kotmale catchment receives average annual rainfall of $2000 \mathrm{~mm}$ to $4500 \mathrm{~mm}$ [24] the degradation of water quality due to sedimentation and eutrophication are causing the reduction of economic use of stored water in Kotmale reservoir [25], [26], [27]. In spite of all, during recent decades, annually, reservoir went down to dead storage and even old sunken monuments were also visible at that period [28], [29].

\section{Data and Methodology}

Daily rainfall data of 9meteorological stations (data period between 1960 and 2005) were used in this study (Table 1). These data were managed, archived and undertook quality control by Department of Meteorology, Sri Lanka [30]. Identification of outliers,extreme values, drifts in the data and cross correlation analysis were done to obtain robust quality data for the study. Inflow data of Kotmale reservoir for the duration of 1984 - 2012 was also collected from Mahaweli Authority of Sri Lanka (MASL). Sea surface temperature (SST) values over Nino 3 region were extracted from the Japan Meteorological Agency website [31]. Nino 3 regions was selected for this study because the focus of much activity related to ENSO has been the Nino 3 region, defined as $5^{0} \mathrm{~N}-5^{0} \mathrm{~S}, 9^{0}-150^{\circ} \mathrm{W}$ and primary predicted ENSO related quantity by models verified by observed data [32].

Table 1 - Description of the 9meteorological stations used for the study

\begin{tabular}{|l|l|r|r|}
\hline No: & Station Name & $\begin{array}{l}\text { Extent } \\
(\mathrm{Ha})\end{array}$ & $\begin{array}{l}\text { Average } \\
\text { annual } \\
\text { rainfall } \\
(\mathrm{mm})\end{array}$ \\
\hline 1 & Ambewela & 5423.07 & 2352.8 \\
\hline 2 & Annfield & 4457.78 & 2771.3 \\
\hline 3 & Campion & 988.75 & 2367.9 \\
\hline 4 & Helboda North & 3729.47 & 3588.8 \\
\hline 5 & $\begin{array}{l}\text { Holmwood } \\
\text { Estate }\end{array}$ & 6994.04 & 2195.7 \\
\hline 6 & Labukelle Estate & 7530.54 & 3051.8 \\
\hline 7 & Oonagalla Estate & 5821.44 & 3531.5 \\
\hline 8 & Sandringham & 6797.05 & 2201.1 \\
\hline 9 & Watawala & 166.00 & 4937.3 \\
\hline
\end{tabular}

The daily rainfall data were plotted to analyse the monthly rainfall variations for each station. Time series analysis of rainfall was carried for each station for 6 seasons \{i.e. DecemberJanuary (DJF), March-May (MAM), June- 
August (JJA), June-September (JJAS), September-November (SON) and OctoberDecember (OND)\}. The mean monthly rainfall values for each station and each season were correlated with the mean SST data over the Nino 3 region to identify relationship between rainfall and SST. The cold ENSO phases were identified which anomaly of monthly SST over Nino 3 region was equal or less than $-0.5^{\circ} \mathrm{C}$. Finally, the monthly rainfall anomalies of each station were examined for the coldENSO phases to understand the variability of rainfall over the catchment.

\section{Results and Discussion}

\subsection{Quality assessment of station data}

Quality assessment of the data; identification of outliers, cross checks for extreme values, checks for drifts in the data and cross correlation analysis was done by the method developed for Kelani catchment by a previous study [30]. Based on the mentioned method all the stations data contained in the range of -0.5 to +0.5 for relationship with anomaly and root mean square error (RMSE). However, RMSE shall deviate with the observed range based on the missing data[12], [33]. All the stations are having low frequency variations, which indicates the absence of extreme outliers. Further, all the stations showed significant correlations with each other. Therefore, based on the quality assessment criteria, data from all the stations are satisfied and used for the required further analysis in this study.

\subsection{Observed rainfall trends}

Annual rainfall trend for each station shows different rates of decreasing trend throughout the selected time duration. The highest decreasing trend observed for Holmwood Estate (Figure 1) and on the other hand the lowest decreasing trend observed for Watawala station (Figure 2).Literature showed that rainfall at these study stations had decreased during recent several decades due to the deforestation in the southern parts of Sri Lanka to facilitate urban requirements[34], [35]. Furthermore, these stations are located at higher elevations of Sri Lanka and during the last century the annual rainfall received for the high elevations in Sri Lanka had decreased[35], [36].

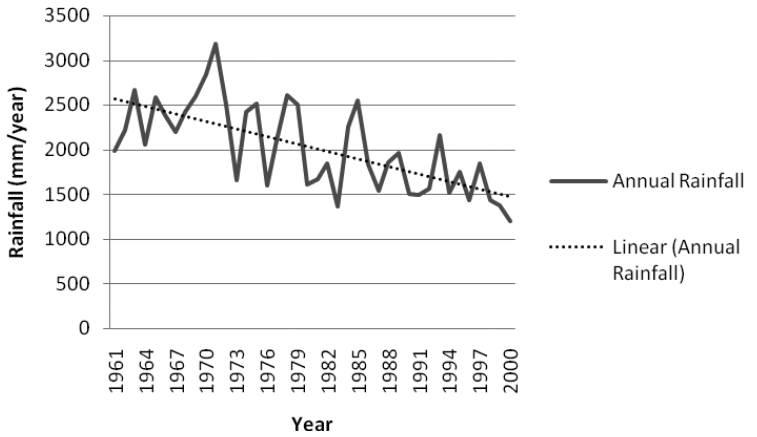

Figure 1 - Decreasing annual rainfall at the Holmwood Estate station

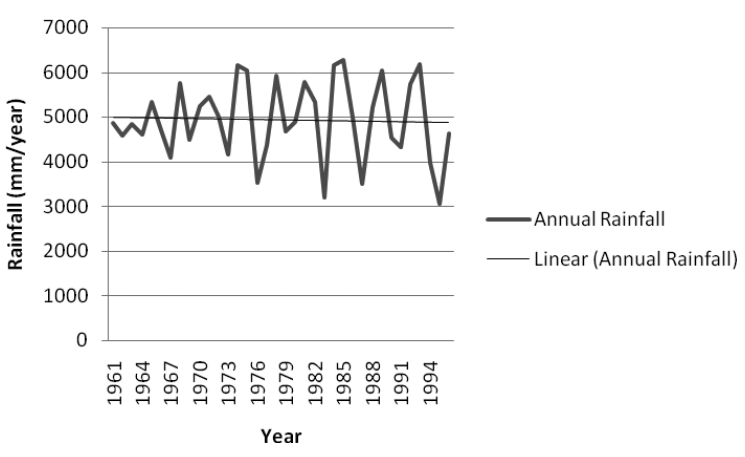

Figure 2 - Decreasing annual rainfall at the Watawala station

\subsection{Identification of ENSO impact on} rainfall

The seasonal rainfall (i.e. DJF, MAM, JJA, JJAS, SON and OND) of Oonagalla Estate showed negative correlation with the mean SST over Nino 3 region. At Watawala station, except for the OND season, rest of the seasonal rainfall showed negative correlation with the SST. The negative correlation betweenSST and the seasonal rainfall of DJF, MAM, JJA and JJAS was observed for the rest of the stations(Correlation between the seasonal rainfall and the SST during DJF season for Oonagalla Estate has shown in the Figure 3 as representative figure for the above mentioned explanation). On the other hand a positive correlation was observed during SON and OND for the same stations, except Watawala station. Watawala station showed negative correlation with seasonal rainfall and SST during SON (Table 2). However, correlation during JJA, SON and OND seasons for Campion station; JJA and JJAS seasons for Holmwood Estate; and Labukelle Estate stations; JJA and OND seasons for Sandringham station are statistically significant (i.e. $p$ value is less than the 0.05) when compared with other correlation values (Table 2). 


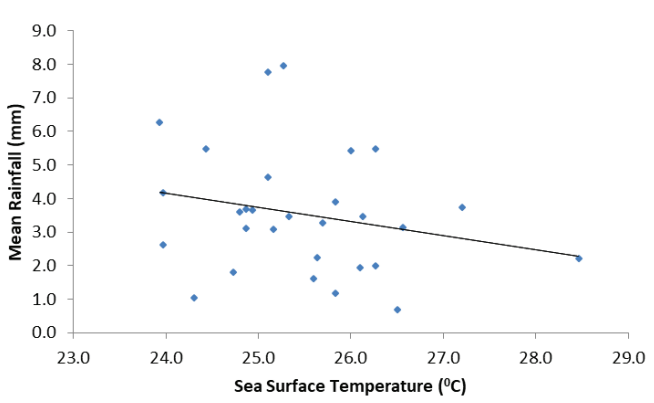

Figure 3 - Correlation between the SST and mean rainfall of Oonagalla Estate station during DJF season (straight line denotes the trend line)

\subsection{ENSO impact on the seasonal rainfall}

The cold ENSO phase is identified based on the threshold level of $-0.5^{\circ} \mathrm{C}$ SST anomaly, but we found years of higher cooling ENSO phases where SST anomaly is more than $-1^{\circ} \mathrm{C}$ were observed during 1970, 1975 and 1999. Further, majority of cold ENSO phases falls in the DJF, SON and OND seasons and MAM season does not contain many number of cold ENSO phases when compared with other 6 seasons.

The rainfall during cold ENSO phases on DJF season did not show a significant deviation from the average seasonal rainfall for entire study period. However, Campion and Helboda North station had above-average seasonal rainfall for many number of cold ENSO phases during DJF season. Below-average seasonal rainfall was prominent for Watawala station during DJF season.

Above-average seasonal rainfall was prominent under the cold ENSO phases during MAM season for the Kotmale catchment. Ambewela station had above-average seasonal rainfall for most of the cold ENSO phases during MAM season. However, in 1964 and 1967 cold ENSO phases had a significant impact on the MAM seasonal rainfall of all the stations and had below-average seasonal rainfall. Furthermore, all the stations had most amount of belowaverage rainfall during mentioned years compared to the other years, which had belowaverage rainfall. In 1967 cold ENSO phase hit worst on Watawala station and had highest below-average seasonal rainfall of $-486.6 \mathrm{~mm}$. On the other hand, during MAM seasons in 1985 and 1989, all the stations had aboveaverage seasonal rainfall.
During cold ENSO phases, above-average seasonal rainfall was prominent during JJA season for Kotmale catchment. Holmwood Estate station showed above-average seasonal rainfall for most number of cold ENSO phases during JJA season. In 1975 and 1978, all the stations observed above-average JJA seasonal rainfall during cold ENSO phases. However, all the stations, except Holmwood Estate, station had below-average JJA seasonal rainfall on 1964 and 1970.

For JJAS season, above-average seasonal rainfall was more prominent compared to the rest of the seasons. Oonagalla Estate station showed above-average seasonal rainfall for most number of cold ENSO phases during JJAS season. Furthermore, all the stations showed above-average seasonal rainfall during cold ENSO phases in 1971, 1975, 1978 and 1984.

During SON season, above-average seasonal rainfall was prominent with the presence of cold ENSO phases for Kotmale catchment. Oonagalla Estate station showed more number of above-average rainfall during cold ENSO phases in SON season. On the other hand, Campion station had more number of belowaverage rainfall during cold ENSO phases in SON season. However, on 1995 ENSO cold phase impacted considerably on Watawala station and caused compelling drop of seasonal rainfall (i.e. - $1047.78 \mathrm{~mm}$ ).

Compared to other seasons, in OND season below-average seasonal rainfall was prominent during cold ENSO phases for Kotmale catchment. Ambewela station received belowaverage seasonal rainfall for more number of cold ENSO phases during OND season. The cold ENSO phase during 1988 influenced all the stations to experience below-average seasonal rainfall for OND season. However, Oonagalla station received above-average seasonal rainfall during OND season for more number of cold ENSO phases. Furthermore, at the presence of cold ENSO phases in 1967, 1970 and 1975, all the stations received above-average seasonal rainfall during OND season. Further, in 1975 Watawala station received the highest aboveaverage seasonal rainfall of $+1010.64 \mathrm{~mm}$ during OND season.

In addition to ENSO, there are other phenomena which could influence seasonal rainfall over Sri Lanka. Since, Sri Lanka is comparatively a small Island, ocean conditions around the country can modify the El-Nino 
effect [37]. Indian Ocean sea surface temperature is the important factor influencing the circulation or rainfall over Indian Ocean rim countries. Indian Ocean Dipole (IOD) plays an important role as a modulator of rainfall in Sri Lanka [38]. Furthermore, the influence of IOD and ENSO are statistically inter-linked and the IOD influence will be highly significant even when there is no ENSO influence and when the two are in competition, the IOD influence will prevail dominantly over that of ENSO [39].

Asian Brown Clouds or presently known as Atmospheric Brown Clouds (ABC) are widespread pollution clouds that can at times span an entire continent or an ocean basin. The demining effect (i.e. cooling effect) by the ABC's reduces the strength of Asian monsoon circulation and evaporation [40], [41], [42]. Therefore, ABC could have animpact on the seasonal rainfall over Sri Lanka.

4.5 ENSO impacts on the inflow of Kotmale reservoir

Annual trend of inflow of Kotmale reservoir demonstrates decreasing trend (Figure 4). As discussed above, the amount of rainfall received at the study stations decreased with time.

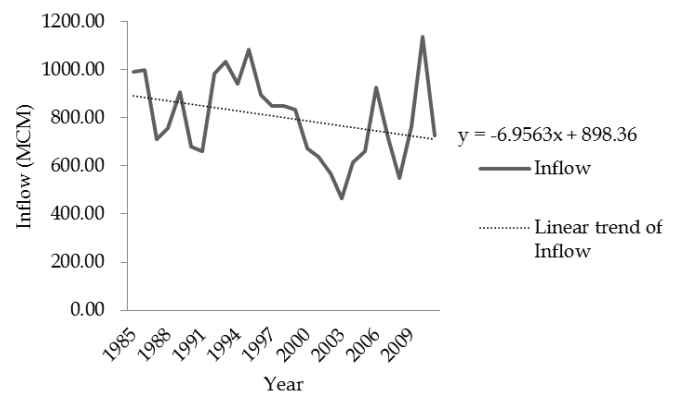

Figure 4 - Changes in inflow of Kotmale reservoir for 1985-2009

The inflow of Kotmale reservoir during June to November is higher than the remaining months of the year (Figure 5).

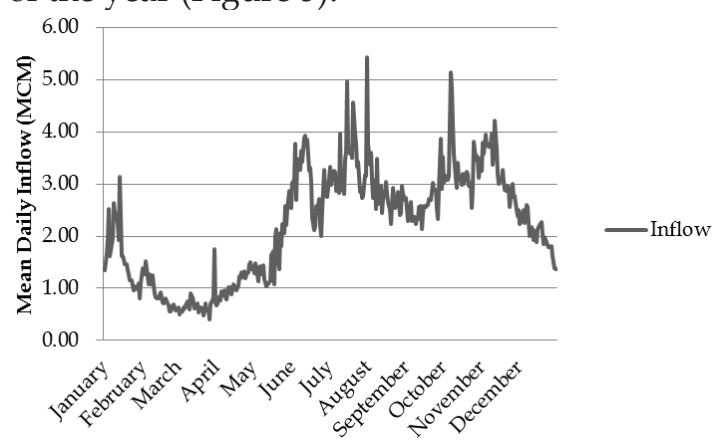

Figure 5 - Daily mean inflow (MCM) for Kotmale reservoir
Furthermore, the inflow of the reservoir was decreasing during DJF season (Figure 5). Kotmale catchment received below-average seasonal rainfall under warm ENSO phases during DJF season[12]. As discussed above, for the same season, presence of cold ENSO phase also gave below-average seasonal rainfall. Further, during DJF season simulated daily mean river discharges were lower compared to other seasons at Talawakele intake dam, AgarapathanaOya and NanuOya which representing the upper Kotmale catchment [43]. Therefore, the amount of runoff generated for the catchment during DJF season is low.

However, during MAM season, the inflow of the reservoir was showing a significant increase until it reaches the peak inflow in June (figure 4). During MAM season, the catchment is receiving more than 150-175 $\mathrm{mm}$ monthly rainfall [44] above-average seasonal rainfall at presence of cold ENSO phases.

The inflow of Kotmale reservoir is decreasing during both JJA and JJAS seasons (Figure 5). Seasonal rainfall received during these seasons undercold ENSO phases contributed more to the catchment than the warm ENSO phases. Because both the seasonal rainfall during warm and cold ENSO phases observed below-average rainfall[12].

Month of October showed high amount of inflow to Kotmale reservoir (Figure 5). Further, during SON season, the inflow of reservoir was increasing (Figure 5). It could be due to aboveaverage rainfall recorded during $\mathrm{SON}$ season in the presence of both warm and cold ENSO phases[12], [43].

November afterwards, the daily mean inflow to the reservoir decreased remarkably until February (Figure 5). As discussed above, during OND season below-average seasonal rainfall is prominant for cold ENSO phases. But the above-average seasonal rainfall during warm ENSO phases for the same season [12] did not inlfuence much on the increase in daily mean inlfow to the reservoir.

\section{Conclusions}

Rainfall patterns for each station showed decreasing trend in the period 1960 to 2005. Deforestation in southern parts of Sri Lanka could be identified as leading cause of the rainfall reduction in these areas. Therefore, annual change in average daily inflow to the 
Kotmale reservoir also showed a decreasing trend during the mentioned period.

As mentioned in previous paragraphs NorthEast Monsoon (NEM) season in Sri Lanka falls on December to January. Over the Kotmale catchment during NEM, the seasonal rainfall does not influenced by the cold ENSO phases and observed rainfall more or less similar to the average seasonal rainfall. However, daily mean flow of the reservoir showed significant decrease during DJF season. Furthermore, previous studies showed that, at the presence of warm ENSO phase, below-average rainfall was observed for these stations.

During onset of NEM (i.e. October to December), the Kotmale catchment received below-average rainfall during cold ENSO phases.

These imply that, during the onset of NEM and during the NEM seasons, the Kotmale catchment is being highly influenced by SST over Nino 3 region and could observe belowaverage rainfall. Therefore, during onset of NEM the effective water management strategies has to be adopted for the water demand management.

Onset of South-west monsoon (SWM) falls during March to April months and occurrence of above-average rainfall was prominent in the Kotmale catchment during cold ENSO phase. However, there were certain years which showed worst below-average seasonal rainfall in the catchment with the presence of cold ENSO phases during SWM. Further studies are necessary to identify hidden coupled teleconnections (i. between seasonal rainfall and the other factors such as sea level pressure, $\mathrm{ABC}$, IOD etc.) to identify the phenomenon which gives worst below average rainfall.

During SWM (i.e. May to September) aboveaverage rainfall was prominent for the catchment, but reservoir inflow showed slight decrease during this period.

\section{Acknowledgement}

This work is supported by the Korea Agency for Infrastructure Technology Advancement(KAIA) grant funded by the Ministry of Land, Infrastructure and Transport (Grant 18AWMP-B121100-03).
Author wishes to acknowledge the assistance and necessary facilities given by the APEC Climate Center (APCC), South Korea. The station datasets provided by the Sri Lanka Meteorological Department and Mahaweli Authority of Sri Lanka are duly acknowledged. The Journal Editor and the reviewers are also thanked for the comments they provided to help improve the manuscript.

\section{References}

1. Ropelewski, C. F., \& Halpert, M. S., “Global and Regional Scale Precipitation Pattern Associated with El Nino/Southern Oscillation", Monthly Weather Review, Vol. 115, 1987, pp. 1606-1626.

2. Fernando, T. K., Jayathilake Banda, P. M., \& Chandrapala, L., "Recent ENSO Events in Sri Lanka-A Comprehensive Study of the Droughts of 1983, 1987 \& 1992", Proc., International Symposium on Climate and Life in the Asia Pacific, University of Brunei, Darrusalam, 1995.

3. Kane, R. P.,"ENSO Relationships to the Rainfall of Sri Lanka", International Journal of Climatology, Vol. 18, 1998, pp. 859-871.

4. Malmgren, B. A., Hulugalla, R., Hayashi, Y., \& Mikami, T., "Precipitation Trends in Sri Lanka since the 1870s and Relationships to El NinoSouthern Oscillation", International Journal of Climatology, Vol. 23 (10), 2003, pp. 1235-1252.

5. Punyawardena, B. V. R., \& Cherry, N. J., "Assessment of the Predictability of the Seasonal Rainfall in Ratnapura using Southern Oscillation and its Two Extremes", Journal of the National Science Council of Sri Lanka, Vol. 27, No. 3, 1999, pp. 187-195.

6. Rasmusson, E. M., \& Carpenter, T. H., "The Relationship between Eastern Equatorial Pacific Sea Temperature and Rainfall over India and Sri Lanka", Monthly Weather Review, Vol. 111, 1983, pp. 517-528.

7. Sumathipala, W. L., \& Punyadeva, N. B. P., "Variation of the Rainfall of Sri Lanka in Relation to El Nino", Proc., Annual sessions of the Institute of Physics, Sri Lanka, 1998.

8. Suppiah, R., "Relationship between Indian Ocean Sea Surface Temperature and the Rainfall of Sri Lanka", Journal of the Meteorological Society of Japan, Vol. 66, 1988. pp. 103-112.

9. Suppiah, R., "Relationships between the Southern Oscillation and the Rainfall of Sri Lanka", International Journal of Climatology, Vol. 9, 1989, pp. 601-618. 
10. Suppiah, R., "Spatial and Temporal Variations in the Relationships between the Southern Oscillation Phenomenon and the Rainfall of Sri Lanka", International Journal of Climatology, Vol. 16, 1996, pp. 1391-1407.

11. Suppiah, R., "Extremes of the Southern Oscillation Phenomenon and the Rainfall of Sri Lanka", International Journal of Climatology, Vol. 17, 1997, pp. 87-101.

12. Chandrasekara, S. S. K., Chandrasekara, S. K., Prasanna, V. \& Kwon, H-H., "Investigation the Teleconnection between Warm ENSO Phases and Seasonal Rainfall over Kotmale Catchment - Sri Lanka", ENGINEER, LI (01), 2018, pp. 1-7.

13. Zubair, L., "Sensitivity of Kelani streamflow in Sri Lanka to ENSO", Hydrological Processes, Vol. 17 (12), 2003, pp. 2439-2448.

14. Zubair, L., \& Ropelewski, C. F., “The Strengthening Relationship of ENSO and the North-East Monsoon Rainfall over Sri Lanka and Southern India", Journal of Climate, Vol. 19 (8), 2006, pp. 1567-1575.

15.Allen, R., Lindsey, J., Parker, D., "El-Nino Southern Oscillation and climate variability", CSIRO Publishing, Collingwood, Victoria, Australia, 1996, 405p.

16. Hanley, D. E., Bourassa, M. A., O'Brien, J. J., Smith, S. R. \& Spade, E. R., " A Quantitative Evaluation of ENSO indices", Journal of Climate, Vol. 16(8), 2003, pp. 1249-1258.

17. Mirza, M. M. Q., "Climate Change, Flooding in South Asia and Implications", Regional Environmental Change, Vol. 11, 2011, pp. 95-107.

18.Zubair, L., "El-Nino Southern Oscillation Influences on the Mahaweli Streamflow in Sri Lanka", International Journal of Climatology, Vol. 23, 2003, pp. 91-102.

19. Zubair, L., Siriwardhana, M., Chandimala, J. \& Yahiya, Z., "Predictability of Sri Lankan Rainfall Based on ENSO", International Journal of Climatology, 2008, Vol. 28. pp. 91-101.

20. Kumar, K. K., Rajagopalan, B., \& Cane, M. A., "On the Weakening Relationship between the Indian Monsoon and ENSO", Science, Vol. 284, 1999, pp. 2156-2159.

21. Jayakody, P. M., "The Influence of La Nina on Sri Lanka Rainfall", Sri Lanka Journal of Meteorology, Vol. 1, 2015. pp. 41-49.

22.http://www.mahawelicomplex.lk/image/sys.jpg ,Visited, 2017/08/01.
23. http://mahaweli.gov.lk/en/complete.html\# Visited, 2017/01/27.

24.De Silva, R. P., \& Chandrasekara, M.,"Impact of Land use Changes on Hydrological Regime; A Case Study of Randenigala \& Kotmale Catchments in Sri Lanka", Proc., Map of Asia 2002, Thailand.

25. Abeysinghe, K. G. A. M. C. S., Nandalal, K. D. W. \& Piyasiri, S., "Prediction of Thermal Stratification of the Kotmale Reservoir using a Hydrodynamic Model", Journal of National Science Foundation Sri Lanka, Vol. 33 (1), 2005, pp. 25-36.

26. Haturusinha, R. L. and Ediriweera, S. W. "Maintenance and conservation of dams in Sri Lanka", In: Dam Maintenance and Rehabilitation.Eds. Llanos, J. A., Yague, J., Sanz de Ormijana, F., Cabrera, M. and Penas, J. Swets \& Zeitlinger, Lisse.Proc., International Congress on Conservation and Rehabilitation of Dams, 2003.

27. Piyasiri, S., "Eutrophication and blue green algal bloom problem of Kotmale reservoir in Sri Lanka", Satya Wacana University Press, Salatiga, Indonesia, 1995.

28.http://geoinfo.mrt.ac.lk/waterresources/publicat ions/D028.pdf, Visited, 2017/01/25

29. Dilini, W. M. N., Lyanage-Hansen, L., Attygalle, M. T. D., \& Nandalal, K. D. W., "Effective Water Management in the Mahaweli Reservoir System; Analyzing the Inflow of the Upmost Reservoir", Proc., International Symposium for Next Generation Infrastructure, October, 2013.

30. Chandimala, J., \& Zubair, L., "Predictability of Stream Flow and Rainfall based on ENSO for Water Resources Management in Sri Lanka", Vol. 335, 2007, pp. 303-312.

31.ftp://www.coaps.fsu.edu/pub/JMA_SST_Index/ Visited, 2017/07/24.

32.Trenberth, K. E., "The definition of El Nino", Bulletin of the American Meteorological Society, American Meteorological Society, 1997. Pp. 27712777.

33.Chandrasekara, S. \& Prasanna, V., "MJO and ENSO interactions on monsoonal rainfall over Sri Lanka". APEC Climate Center. Young Scientist Support Program 2012. Final Report. APCC YSSP Final report 2012-01, Republic of Korea, 2013, pp. 474-499.

34.http://en.wikipedia.org/wiki/Holmwood_Estate, Visited, 2012/11/11.

35.http://rainforests.mongabay.com/deforestation/ archive/Sri_Lanka.htm, Visited, 2012/11/11. 
36. http://publications.iwmi.org/pdf/H042865.pdf, Visited, 2017/07/19.

37. Sumathipala, W. L., "EL-Nino - A Short Term Signal of a Long Term and a Large Scale CLimate Variation", Journal of National Science Foundation Sri Lanka, Vol. 42, No.3, 2014, pp. 199-200.

38. Jayawardene, H. K. W. I., Jayawardena, D. R., \& Sonnadara, D. U. J., "Interannual Variability of Precipitation in Sri Lanka". Journal of National Science Foundation Sri Lanka, Vol. 43, No. 1, 2015, pp. $75-82$.

39. Zubair, L., Rao, S. A., \& Yamagata, T., "Modulation of Sri Lankan Maha Rainfall by the Indian Ocean Dipole", Geophysical Research Letters, Vol. 30, No. 2, 2003, pp. 35-1-35-4.

40. Ganguly, D., Rasch, P. J., Wang, H., \& Yoon, J-H., "Climate Response of the South Asian Monsson System to Anthropogenic Aerosols", Journal of Geophysical Research, Vol. 117 (D13209), 2012, pp.1-20.
41. Meehl, G. A., Arblaster, J. M., \& Collins, W. D., "Effects of Black Carbon Aerosols on the Indian Monsoon", Journal of Climate, Vol. 21, 2008, pp. 2869-2882.

42. Ramanathan, V., Aggrawal, M., Akimoto, H., Auffhammer, M., Devotta, S., \& Emberson, L. Atmospheric Brown Clouds: Regional assessment report with focus on Asia". Nairobi: United Nations Environment Programme.

43.

https://www.researchgate.net/profile/Akalanka Silva/publication/308789672_ESTIMATION_O F_ANNUAL_SEDIMENT_LOAD_IN_KOTMALE OYA_UPPER_KOTMALE_BASIN_SRI_LANKA /links/57f1cbdc08ae91deaa561715/ESTIMATIO N-OF-ANNUAL-SEDIMENT-LOAD-INKOTMALE-OYA-UPPER-KOTMALE-BASINSRI-LANKA.pdf, Visited, 2018/11/09.

44

http://www.statistics.gov.lk/Abstract2014/CHA P1/1.6.pdf, Visited, 2018/11/14.

Table 2 - Correlation coefficients between SST and seasonal mean rainfall of the Kotmale catchment.

\begin{tabular}{|c|c|c|c|c|c|c|c|}
\hline & & DJF & MAM & JJA & JJAS & SON & OND \\
\hline \multirow[b]{2}{*}{ Annfield } & Correlation & -0.08 & -0.08 & -0.27 & -0.25 & 0.02 & 0.21 \\
\hline & P Value & 0.579 & 0.601 & 0.076 & 0.09 & 0.879 & 0.156 \\
\hline \multirow[b]{2}{*}{ Ambewela } & Correlation & -0.07 & -0.24 & -0.23 & -0.22 & 0.20 & 0.27 \\
\hline & P Value & 0.660 & 0.130 & 0.152 & 0.177 & 0.215 & 0.097 \\
\hline \multirow[b]{2}{*}{ Campion } & Correlation & -0.19 & -0.22 & -0.31 & -0.20 & 0.39 & 0.39 \\
\hline & P Value & 0.197 & 0.138 & 0.032 & 0.177 & 0.006 & 0.006 \\
\hline \multirow{2}{*}{$\begin{array}{l}\text { Helboda } \\
\text { North }\end{array}$} & Correlation & -0.28 & -0.10 & -0.25 & -0.27 & 0.09 & 0.24 \\
\hline & P Value & 0.064 & 0.502 & 0.091 & 0.071 & 0.558 & 0.117 \\
\hline \multirow{2}{*}{$\begin{array}{l}\text { Holmwood } \\
\text { Estate }\end{array}$} & Correlation & -0.25 & -0.22 & 0.47 & -0.40 & 0.07 & 0.11 \\
\hline & P Value & 0.123 & 0.181 & 0.002 & 0.011 & 0.672 & 0.497 \\
\hline \multirow{2}{*}{$\begin{array}{l}\text { Labukelle } \\
\text { Estate }\end{array}$} & Correlation & -0.25 & -0.22 & -0.30 & -0.34 & 0.03 & 0.15 \\
\hline & P Value & 0.096 & 0.146 & 0.042 & 0.021 & 0.830 & 0.335 \\
\hline \multirow{2}{*}{$\begin{array}{l}\text { Oonagalla } \\
\text { Estate }\end{array}$} & Correlation & -0.23 & -0.13 & -0.29 & -0.31 & -0.16 & -0.06 \\
\hline & P Value & 0.221 & 0.515 & 0.126 & 0.162 & 0.422 & 0.768 \\
\hline \multirow[b]{2}{*}{ Sandringham } & Correlation & -0.08 & -0.27 & -0.38 & -0.28 & 0.25 & 0.33 \\
\hline & P Value & 0.586 & 0.071 & 0.009 & 0.057 & 0.079 & 0.019 \\
\hline \multirow[b]{2}{*}{ Watawala } & Correlation & -0.12 & -0.12 & -0.25 & -0.32 & -0.12 & 0.02 \\
\hline & P Value & 0.501 & 0.486 & 0.147 & 0.060 & 0.499 & 0.659 \\
\hline
\end{tabular}

